personal experience and observation, such is often the case. So the teacher in any subject may say to the student: "If you make grammatical blunders, it proves that you are not mature enough to realize the value of your mother tongue. We shall consequently keep you in your present English grade until you grow up. If, on the other hand, your presentation of the facts and principles of physics or cooking or mechanical drawing or economics is confused and obscure, it proves conclusively that you have been guilty of a crime of deeper dye-the crime of not understanding $m e$; and so of course I shall certainly keep you here in my class for a sufficient period longer."

For the definite work of cooperation, the plan in use at the Cicero, Ill., high school seems the best. This, as it is described in accesssible records, I recommend to the attention of interested readers.

\title{
OUTSIDE OF CLASSROOM ACTIVITIES IN SCIENCE.
}

By L. C. Feldmann, High School, Oshkosh, Wis.

W. L. Lane of the Survey Staff after a detailed study of the English school system under war conditions made the following statement:1 "One good has" however, come out of all this"referring to the use of school buildings for barracks-" "and this is the school journeys that have been resorted to in order to fill in the time which can not be spent in the classrooms." Referring to a particular class, in which outside work had been done, he said: "Within six months the class had become so much more alert and interested in its work than it had been before, that the instructor begged to be permitted to continue these journeys even after the school had been restored to its educational use." In order to determine the extent to which these methods are employed, the following questionnaire was sent to Wisconsin High Schools, chosen at random out of the school directory issued by the State Department of Education.

Out of the forty-eight letters sent out, thirty-seven replies were received. In two cases the information obtained was of an indefinite nature, and consequently has not been included in the tabulations.

In answer to my request for personal letters only three schools, numbers 8,11 , and 36 responded. In each case the writer excused the small amount of outside activity because of the shortness of the periods and because of the prohibitive amount of work on the part of the instructor.

isurvey, Feb. 3, 1917. 
Dear Fellow Teacher:

I am enclosing a set of questions which I wish you would fill out and return to me in the enclosed stamped envelope. If some of the subjects mentioned are taught by some other teacher, will you please obtain the information from that teacher, and then fill in in the proper spaces?

I should appreciate a personal letter stating more in detail what you are doing in the line of outside activities in connection with your science work.

1 .

\begin{tabular}{l|l|l|}
\hline Class & Approx. & $\begin{array}{c}\text { Number of Where to are trips taken } \\
\text { trips. }\end{array}$ \\
Physies. & & \\
Botany. & \\
Ele. Science- & \\
Agrieulture &
\end{tabular}

2. Is there a Seience Club or similar club in your school?

3 . If so, what is accomplished by it?

4. Number of members? (b) Number of pupils in school?

5. Are any attempts made to create an interest in seience in pupils who are not taking any science subjects?

6. What are they?

In reply to the first excuse I can only say that if the periods are so short that trips cannot be undertaken in the allotted laboratory time, the curriculum has not been properly balanced, and should be rearranged. However, I have found a double period of forty minutes each affording ample time for all ordinary excursions. And under exceptional conditions different arrangements can be made. As for the teachers having too much work, if that is the case; then the teaching force should be enlarged, for we cannot afford to have the rising generation taught in a helter-skelter fashion. The problems the men and women of tomorrow will have to grapple with will be too difficult to solve with such a preparation as a foundation. However, it is my firm conviction that the overworked teacher would find relief in taking a physics class to the power plant or to the telephone exchange and have the person in charge of the plant explain the workings of the same. In order to prepare a lesson of this kind all that is necessary is to telephone for permission to visit the respective plants and arrange for a guide. Surely, this is not so much work and does not take as much time as is required in preparing the regular laboratory exercises.

Thus much for the excuses. More interesting conditions are revealed as the answers to the six questions are compiled.

Tables I and II take in all the data under question I. In tabulating the results, the total obtained by adding the number of trips taken by each class in that subject was divided by the number of classes entering into the making of the total; thus giving the average. For example, in physies the thirty- 


\begin{tabular}{|c|c|c|c|c|c|}
\hline \multicolumn{2}{|c|}{ TABLE NO. 1.} & \multicolumn{4}{|c|}{ NO. OF TRIPS TAKEN IN: } \\
\hline $\begin{array}{l}\text { School } \\
\text { Number }\end{array}$ & $\begin{array}{c}\text { Approx. } \\
\text { Enrollment }\end{array}$ & Physies & Botany & $\begin{array}{l}\text { Elem. } \\
\text { Srience }\end{array}$ & Agricultr. \\
\hline $\begin{array}{r}1 \\
2 \\
3 \\
4 \\
5 \\
6 \\
7 \\
8 \\
9 \\
10 \\
11 \\
12 \\
13 \\
14 \\
15 \\
16 \\
17 \\
18 \\
19 \\
20 \\
21 \\
22 \\
23 \\
24 \\
25 \\
26 \\
27 \\
28 \\
29 \\
30 \\
31 \\
32 \\
33 \\
34 \\
35 \\
36 \\
37\end{array}$ & $\begin{array}{r}70 \\
39 \\
265 \\
20 \\
90 \\
65 \\
83 \\
105 \\
120 \\
125 \\
99 \\
72 \\
80 \\
810 \\
109 \\
310 \\
400 \\
135 \\
120 \\
800 \\
270 \\
75 \\
46 \\
240 \\
25 \\
95 \\
75 \\
\\
105 \\
115 \\
130 \\
89 \\
78 \\
83 \\
460 \\
216 \\
280\end{array}$ & $\begin{array}{l}4 \\
1 \\
1 \\
4 \\
1 \\
0 \\
2 \\
1 \\
2 \\
1 \\
0 \\
0 \\
7 \\
0 \\
5 \\
5 \\
2 \\
4 \\
\\
3 \\
4 \\
1 \\
1 \\
4 \\
0 \\
2 \\
1 \\
2 \\
0 \\
7 \\
0 \\
8 \\
2 \\
4 \\
1 \\
4\end{array}$ & $\begin{array}{r}2 \\
5 \\
0 \\
6 \\
0 \\
0 \\
18 \\
7 \\
0 \\
0 \\
15 \\
0 \\
12 \\
4 \\
4 \\
12 \\
3 \\
\\
0 \\
7 \\
0 \\
5 \\
19 \\
8 \\
2 \\
15 \\
0 \\
6\end{array}$ & $\begin{array}{l}4 \\
0 \\
0 \\
0 \\
0 \\
2 \\
0 \\
0 \\
2 \\
5 \\
0 \\
0 \\
8 \\
0 \\
8 \\
4 \\
0 \\
0 \\
4 \\
2 \\
4 \\
0 \\
2 \\
1 \\
3 \\
1 \\
0 \\
0 \\
7 \\
0 \\
5 \\
0 \\
4 \\
0 \\
0 \\
3\end{array}$ & $\begin{array}{r}0 \\
26 \\
0 \\
2 \\
15 \\
14 \\
0 \\
10 \\
\\
50 \\
7 \\
3 \\
8 \\
2 \\
3 \\
6 \\
\\
2 \\
21 \\
0 \\
0 \\
14 \\
1 \\
5\end{array}$ \\
\hline \multicolumn{2}{|c|}{ Total No. of Trips............. } & 84 & 175 & 69 & 242 \\
\hline \multicolumn{2}{|c|}{ Average No. of Trips } & $22-5$ & 5 & 2 & 7 \\
\hline \multicolumn{2}{|c|}{ 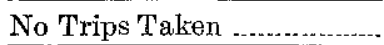 } & 7 & 10 & 10 & 5 \\
\hline
\end{tabular}

five classes took eighty-four trips; or each class took an average of two and two-fifths trips. Seven, or one-fifth of the classes, undertook no trips during the year. In botany the average number of trips is five per class, yet ten teachers taught this subject for which much illustrative material in natural environment is always close at hand without any attempts to utilize it. Elementary science shows an average of two trips per class, but in this case, half the classes went on no trips. Agriculture, a subject which calls for much field work in order to get away from the non-vitalized type of instruction of ten years 
Table No. II

Where Trips were Taken to by Class in:

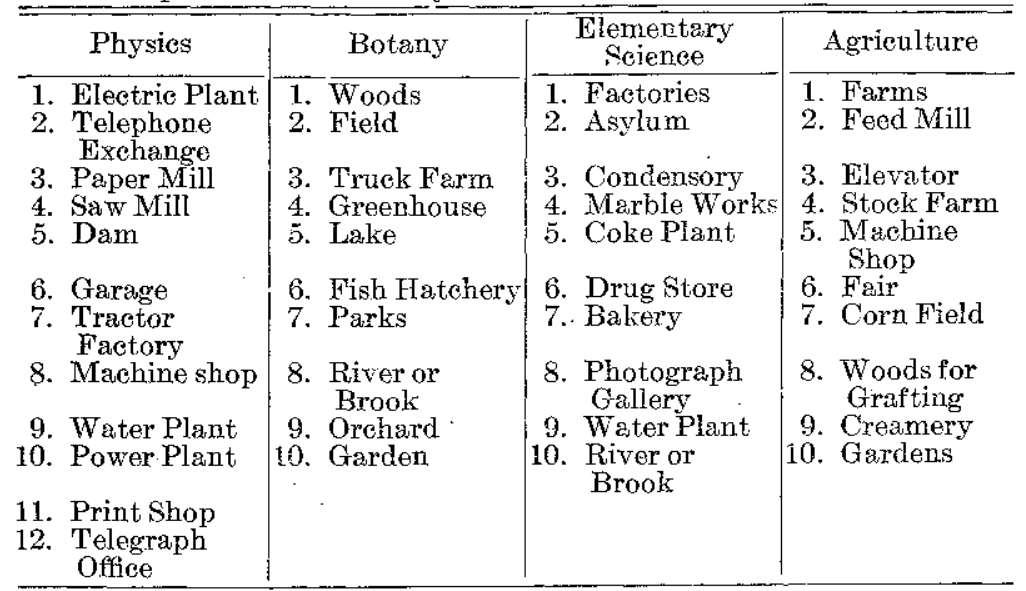

ago, has an average of seven trips per class. Even here, five teachers have made no attempts to vitalize their work by this method.

In Table II a list of the places mentioned by the different teachers as having been visited by their classes has been made. Under physics twelve specific places are mentioned of which numbers $1,2,6,8,9,10$ and 12 are usually found in any village or eity. Botany and agriculture have a very general list with probably numbers 3,4 , and 6 the only places not found in every community. In elementary science where ten specific places are mentioned and two are the average number of trips undertaken, some other reason for this lack of outside activity must be found. Keeping this in mind, note schools number 12, 13, and 29 in which the four subjects mentioned are taught by the same teacher. 2 Number 12 shows no trips in physics or elementary Science, 18 in botany and 26 in agriculture; number 13 gives physics 7 , botany 7 , elementary seience 8 , and agriculture 0 ; number 29 has the following record; Physics 0, botany 19, elementary science 0 , agriculture 21 . The records for schools numbers 12 and 29 seem to indicate that the teacher's particular field was agriculture and botany. Upon further inquiry this was found to be true. ${ }^{3}$ In both cases the instructor had majored in agriculture in college. School number 13 has a record which points to agriculture as the slighted subject. And in this case it was found that the teacher had had no college or practical training in agriculture and taught the subject because the

2.3Verified by personal interview. 
science man was supposed to do so. These results, although meagre, seem to indicate that a teacher can teach only those subjects in which special training has been received, and that some subjects are taught by teachers not adequately prepared to teach them. Now then, let us again think of elementary science. Perhaps in the fact that no special training to teach such a subject has been offered by the college and universities and that it has not been given much of a place on the sectional programs of the leading teachers' association meetings, can be found the reason for the poor record made by it. Or is it perhaps because elementary science, to a great extent, is taught by teachers who would rather work in their chosen fields; such as physics, botany, or agriculture?

In answer to question 2 , six schools indicated that there was an agricultural club in the school, and thirty-one stated that they had no club of a scientific nature. One instructor in answer to this question made the following statement: "With a literary society and debating club it does not seem advisable." Here the impression is given that the attitude, "I'll take care of everything else first, and then comes science," prevails. What the clubs accomplished ean best be judged by several answers to question 3 which follow: (1) meetings are beld semimonthly and topies pertaining to agriculture and poultry are discussed by students; (2) discussion of current farm improvements and study of farm magazines; (3) garden and field projects are undertaken. In each case a marked improvement in alertness was noticed among the students belonging to the club.

The number of members ranged from 15 in the smallest to 40 in the largest club. The average membership for all the clubs was 28.

Like question 2 , questions 5 and 6 do not net much information outside of the fact that very little is done outside of the classroom to interest students, and that a few are opposed to such methods. However, in sixteen instances the opinion expressed was that something not included in classroom work should be attempted. Often this opinion was expressed in unmistakable terms. For example, instructors in schools number 6,14 , and 25 answered thus (school 6): "Not as yet but there should be"; (school 14): "Outside work a sadly neglected feature here"; (school 25): "No, but something ought to be done." In a few schools some attempts are made. School number 9 reports that opening exercises are given over to the discussion of science subjects 
one of the features being to have the person in charge give questions to be reported on later, the answers to these questions to be found in Popular Science. The instructor in school number 22 places newspaper and magazine clippings of scientific interest on a bulletin board and encourages students to bring to him clippings of the same nature to be placed on the board.

Both of these methods are very good and should be more generally used. However, in large schools such methods do not reach all the students, because no general assembly is held every day and not all students visit the class room where the bulletin board is found. Another very good way of reaching the pupils in a school of any size is by means of exhibits.

These exhibits, which will be explained later, should be placed somewhere in corridors near the main entrance, or better still if possible, in some particular place in the library. It is an advantage to place them on a small table or stand used exclusively for the purpose of the exhibition in some well-lighted space, but if necessary, less favorable positions afford sufficient opportunity. A bulletin board immediately behind the table or stand is convenient for pinning up clippings pertaining to the articles on exhibition. A fairly large card or label conspicuously placed on the table or near the top of the bulletin board, naming the project and indicating when changes in the exhibit are made is desirable. As a means of exciting the interest of those who do not take science it is advisable to change the display once a week, preferably on Saturday; but if there is a shortage of illustrative material, a two weeks period is not too long.

In order to help out in this respect the following list of exhibits used by the author and found of interest to the pupils is given:

1. (a) Cecropis moth. (b) Blazing Starflower. (e) Pieture of song sparrow.

2. Asbestos and literature on same.

3. Horlick's malted milk exhibit.

4. Blue print pietures and how to make them.

5. The ores of different minerals.

6. X-ray pieture and literature on electric treatments.

7. (a) Specimen of frog. (b) Several balls of cotton. (c) Pioture of robin

8. Coffee in various stages of preparation.

9. Several different specimens of fungi.

10. How to mount butterfly or moth (the various steps).

11. (a) Zebra swallow-tailed butterfly. (b) Several clams and oysters in the shell.

12. (a) Closed Gentian. (b) Giant water bug.

13. Standard Oil Products exhibit.

14. (a) Piekerel weed. (b) Sea urchin. (c) Picture of gold finch.

15. (a) Synthis moth. (b) Blue jay picture. (c) Starfish.

16. Collecting, pressing and mounting plants.

17. Collecting of rocks. 
18. Artificial fertilizer and efiect on plants.

19. How to prepare any small insect for permanent collection.

This list can be supplemented to a great extent. For example, the experimental field has not been touched and under this, besides many others depēnding on the laboratory apparatus on hand, the following can be shown:

1. Petri dish experiment to show presence of bacteria on different articles.

2. Testing of cloth for adulterations.

3. Copper-plating of a spoon or fork.

4. Illustration of the difference between an acid and a base by action on indicators.

5. Refraction of rays of light by means of a pencil placed so that it is partly. under water.

In each case an appropriate non-technical explanation for each article was given on a four by six card. There was no pretense at arranging the exhibits in any definite order, for it was found advisable to have each exhibit complete in itself rather than have a course of exhibits. By experiment it was found that the present system created more interest in a larger number of pupils than the course of exhibits did.

In conclusion, I will say that I have tried to give to the reader in concrete form the data gathered from other teachers, together with my interpretations, and also those methods which I have found successful while teaching.

\section{COMMERCIAL GEOGRAPHY AS VOCATIONAL GUIDANCE.}

By ANDREW Nichols,

Austin High School, Chicago, Ill.

The daily papers on a recent Sunday showed that the labor market of Chicago demanded men in the following vocations which might be classed as office work: Certified public accountants, cost accountants, senior accountants, bookkeepers, billers and extenders, ledger clerks, cost clerks, general office clerks, adjustment correspondents, addressers, foreign correspondents, mailing clerks, adding-machine operators, railway elerks, stenographers and typists, advertising men, credit and collection men and manager, clerks for insurance offices, bank clerks, placement men for employment agencies, office engineers, office managers, special credit men for banking houses, insurance executives, advertising managers, health and accident club managers, interpreters for professional offices, and time keepers.

In the mercantile field there were calls for buyers and assistant buyers, advertising solicitors, stock clerks and receiving clerks, 